\title{
RETROSPECTIVE STUDY ON BODY SURFACE ABSCESSES IN FARM ANIMALS
}

\author{
MISK T.N. ${ }^{1}$; EL-SHERRY T. ${ }^{2}$ and MISK N.A. ${ }^{3}$ \\ ${ }^{1}$ Department of Surgery, Anesthesiology and Radiology, Faculty of Veterinary Medicine, Sadat City University, \\ Sadat City, Menofia, Egypt. \\ ${ }^{2}$ Department of Pathology, Faculty of Veterinary Medicine, Assiut University, Assiut, Egypt. \\ ${ }^{3}$ Department of Surgery, Anesthesiology and Radiology, Faculty of Veterinary Medicine, Assiut \\ University, Assiut, Egypt.
}

Received: 30 December 2019; Accepted: 23 January 2020

\begin{abstract}
The aim of the present study is to determine the predilection seats of body surface abscesses in some farm animals, their relations to the way of entrance of infection as well as the methods of surgical treatment, fate and complications. The present study was carried out on a total number of 790 animals (buffaloes $=131$, cattle $=$ 240 , sheep $=230$, goats $=81$, donkeys $=64$, horses $=17$ and camels $=27$ ) suffering from presence of abscesses at different localities on the body surface. All cases were recorded during field trips to villages of 27 provinces allover Egypt from 2003 - 2018. Diagnosis was established depending on case history, clinical signs and exploratory puncture. Surgical treatment was performed either by incision of the abscess wall and evacuation of the contents or by total excision. Results indicated that abscesses were detected at the parotid region in 129 animals (16.33\%), mandibular region in 120 animals (15.19\%), sub-conjunctival in 36 animals (4.56\%), cheek region in 33 animals $(4.18 \%)$, ear region in 10 animals $(1.27 \%)$, neck region in 47 animals $(5.95 \%)$, thoracic limbs in 72 animals $(9.11 \%)$, thoracic wall behind the elbow in 34 animals $(4.30 \%)$, abdominal wall in 60 animals $(7.59 \%)$, umbilical region in 68 animals $(8.61 \%)$, gluteal region in 45 animals $(5.70 \%)$, pelvic limbs in 102 animals (12.91\%), tail region in 16 animals $(2.03 \%)$ and vulvar lips in 5 animals $(0.63 \%)$. The results also revealed that the ways of entrance of infection include; breach on the surface of the skin, migrating foreign bodies from the lumen of the digestive tract, iatrogenic by using non-sterilized needle for intramuscular injection, punctured wounds by infected foreign bodies and blood and lymph borne infection. Solitary abscesses were recorded in 682 animals (86.33\%) while multiple abscesses were diagnosed in 108 animals (13.67\%). Surgical treatment was performed by incision and evacuation of abscesses in 686 animals $(86.84 \%)$ and by total excision in 104 animals (13.16\%). Considering the fate of cases after surgical treatment; 589 animals $(74.56 \%)$ recovered after the first surgical interference, 66 animals $(8.35 \%)$ recovered after the second surgical interference after management of complications, 43 animals $(5.44 \%)$ were culling either by slaughtering or euthanasia and 92 animals $(11.65 \%)$ the fate was not recorded postoperatively.
\end{abstract}

Key words: Abscesses, farm animals.

\section{INTRODUCTION}

Abscess is the most common swelling observed on the skin surface of animal body. It is a collection of pus that hollow out a cavity in the tissues by destroying and expanding them. The invading micro-organisms gain entrance into the animal body through a breach in the skin or mucous membrane or transmitted passively into tissues incorporated with infected foreign bodies. Many infectious diseases are characterized by formation of

Corresponding author: Dr. MISK TN.

E-mail address: tarik.misk@vet.usc.edu.eg

Present address: ${ }^{1}$ Department of Surgery, Anesthesiology and Radiology, Faculty of Veterinary Medicine, Sadat City University, Sadat City, Menofia, Egypt. either superficial abscesses underneath the skin or deep abscesses inside tissues and body organs. Bus is the end result of a war established between the invading pyogenic microorganisms and living tissues and cells. It is consisting of a dead and living polymorph nuclear leucocytes, cellular debris, pyogenic microorganisms, lymph and serum (Fubini et al., 2004; Abouelnasr et al., 2016; Sadan et al., 2019 and Misk et al., 2019).

The aim of the present study is to determine the predilection seats of body surface abscesses in some farm animals, their potential causes as well as the methods of surgical treatment, fate and complications after treatment. 


\section{MATERIALS AND METHODS}

The present study was carried out on a total number of 790 animals suffering from presence of abscesses on body surface. All cases were recorded and managed during field trips to villages of 27 provinces allover Egypt during the period from 2003 to 2018. Diagnosis was established depending mainly on case history and clinical presentation of cases. Exploratory puncture was performed for confirmation of diagnosis. The surgical treatment was adopted by either performing a surgical incision through the abscess wall and evacuation of the contents or by total excision of abscesses. The follow up period was extended up to two months. The Predilection seats of abscesses were registered in all examined animals which include; buffaloes $(n=131)$, cattle $(n=240)$, sheep $(n=230)$, goats $(n=81)$, donkeys $(n=64)$, horses $(n=17)$, and camels $(n=27)$. The suspected way of infection was recorded according to the case history, clinical signs and findings during surgery.

The criteria for selecting and analyzing data were; frequency of occurrence of abscesses in animal species, predilection seats of abscesses, potential causes, surgical treatment options either by evacuation of abscesses contents after incision or by en bloc excision of the abscesses, recorded complications and finally, the fate after treatment.

\section{RESULTS}

1- The number of affected animals and the predilection seats of body surface abscesses were summarized in table 1 and Figs 1 and 2.

Table 1: Number of affected animals and the predilection seats of body surface abscesses.

\begin{tabular}{|c|c|c|c|c|c|c|c|c|c|c|c|c|c|c|c|c|}
\hline $\mathrm{N}$ & Animals & 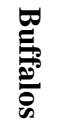 & $\%$ & 芵 & $\%$ & $\begin{array}{l}\mathscr{\mathscr { O }} \\
\frac{\mathbb{8}}{8}\end{array}$ & $\%$ & $\begin{array}{l}\Omega \\
\stackrel{2}{\Rightarrow}\end{array}$ & $\%$ & 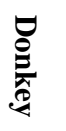 & $\%$ & $\begin{array}{l}\bar{T} \\
\frac{1}{0} \\
\frac{6}{6}\end{array}$ & $\%$ & 氖 & $\%$ & $\overrightarrow{\stackrel{0}{0}}$ \\
\hline 1 & $\begin{array}{l}\text { Parotid } \\
\text { region }\end{array}$ & 5 & 3.8 & 7 & 2.9 & 76 & 33 & 24 & 29.6 & 12 & 18.8 & 0 & 0 & 5 & 18.5 & 129 \\
\hline 2 & $\begin{array}{l}\text { Mandibular } \\
\text { region }\end{array}$ & 4 & 3.1 & 17 & 7.1 & 55 & 23.9 & 16 & 19.8 & 20 & 31.3 & 8 & 47.1 & 0 & 0 & 120 \\
\hline 3 & $\begin{array}{c}\text { Sub- } \\
\text { conjunctival }\end{array}$ & 16 & 12.2 & 15 & 6.3 & 3 & 1.3 & 1 & 1.2 & 1 & 1.6 & 0 & 0 & 0 & 0 & 36 \\
\hline 4 & $\begin{array}{l}\text { Cheek } \\
\text { region }\end{array}$ & 15 & 11.5 & 11 & 4.6 & 3 & 1.3 & 4 & 4.9 & 0 & 0 & 0 & 0 & 0 & 0 & 33 \\
\hline 5 & Ear region & 0 & 0 & 0 & 0 & 3 & 1.3 & 2 & 2.5 & 4 & 6.3 & 0 & 0 & 1 & 3.7 & 10 \\
\hline 6 & Neck region & 7 & 5.3 & 14 & 5.8 & 15 & 6.5 & 3 & 3.7 & 5 & 7.8 & 0 & 0 & 3 & 11.1 & 47 \\
\hline 7 & $\begin{array}{c}\text { Thoracic } \\
\text { limbs }\end{array}$ & 12 & 9.2 & 29 & 12.1 & 14 & 6.1 & 6 & 7.4 & 7 & 10.9 & 2 & 11.8 & 2 & 7.4 & 72 \\
\hline 8 & $\begin{array}{c}\text { Chest wall } \\
\text { behind the } \\
\text { elbow }\end{array}$ & 15 & 11.5 & 14 & 5.8 & 5 & 2.2 & 0 & 0 & 0 & 0 & 0 & 0 & 0 & 0 & 34 \\
\hline 9 & $\begin{array}{c}\text { Abdominal } \\
\text { wall }\end{array}$ & 12 & 9.2 & 5 & 2.1 & 24 & 10.4 & 5 & 6.2 & 3 & 4.7 & 5 & 29.4 & 6 & 22.2 & 60 \\
\hline 10 & $\begin{array}{l}\text { Umbilical } \\
\text { region }\end{array}$ & 25 & 19.1 & 34 & 14.2 & 7 & 3 & 2 & 2.5 & 0 & 0 & 0 & 0 & 0 & 0 & 68 \\
\hline 11 & $\begin{array}{c}\text { Gluteal } \\
\text { region }\end{array}$ & 13 & 9.9 & 23 & 9.6 & 2 & 0.9 & 2 & 2.5 & 2 & 3.1 & 0 & 0 & 3 & 11.1 & 45 \\
\hline 12 & Pelvic limbs & 6 & 4.6 & 61 & 25.4 & 10 & 4.3 & 11 & 13.6 & 8 & 12.5 & 2 & 11.8 & 4 & 14.8 & 102 \\
\hline 13 & $\begin{array}{c}\text { Perineal } \\
\text { region }\end{array}$ & 1 & 0.8 & 5 & 2.1 & 2 & 0.9 & 5 & 6.2 & 0 & 0 & 0 & 0 & 0 & 0 & 13 \\
\hline 14 & Tail region & 0 & 0 & 2 & 0.8 & 11 & 4.8 & 0 & 0 & 0 & 0 & 0 & 0 & 3 & 11.1 & 16 \\
\hline 15 & Vulvar lips & 0 & 0 & 3 & 1.3 & 0 & 0 & 0 & 0 & 2 & 3.1 & 0 & 0 & 0 & 0 & 5 \\
\hline & Total & 131 & & 240 & & 230 & & 81 & & 64 & & 17 & & 27 & & \multirow{2}{*}{790} \\
\hline & $\%$ & 16.5 & & 30.4 & & 29.1 & & 10.3 & & 8.1 & & 2.2 & & 3.4 & & \\
\hline
\end{tabular}



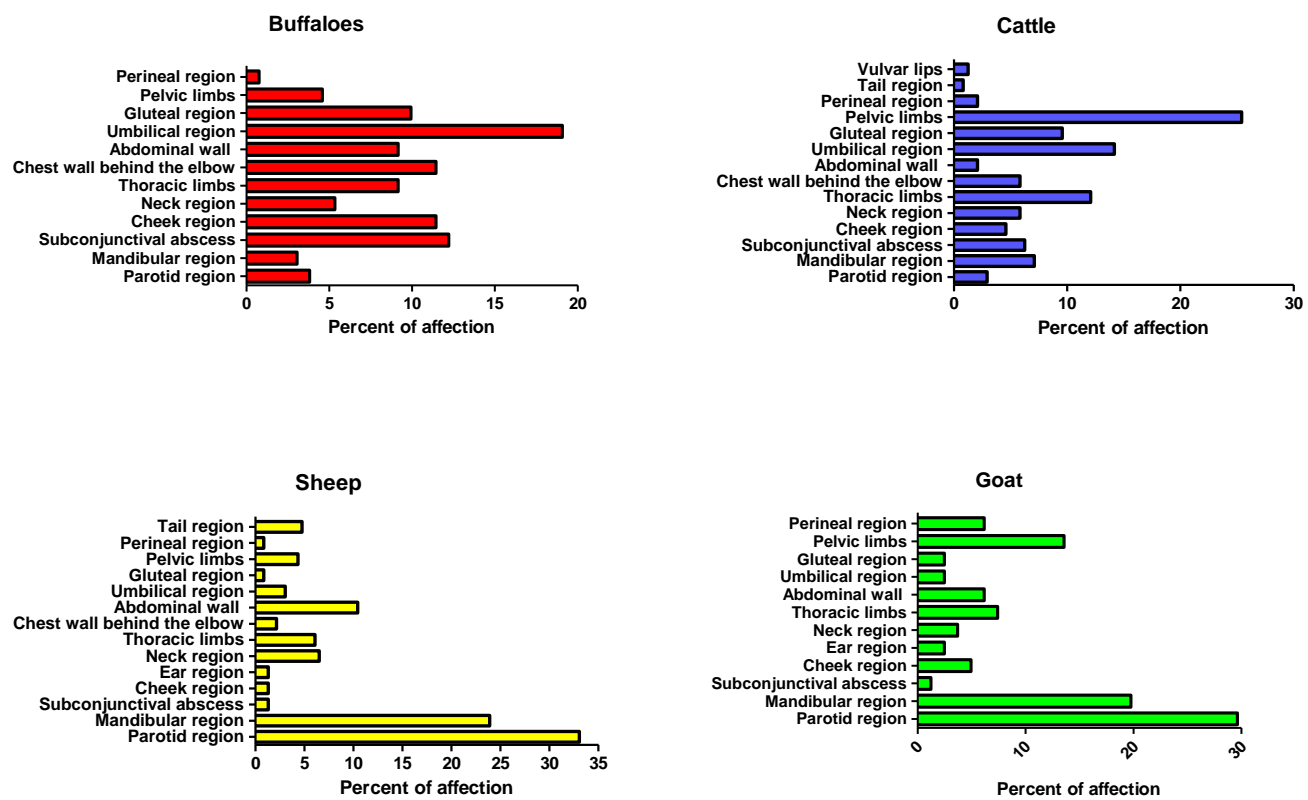

Fig. 1: The percent of affected Cattle, Buffalo, Sheep, and Goat in relation to the seat of body surface abscesses.
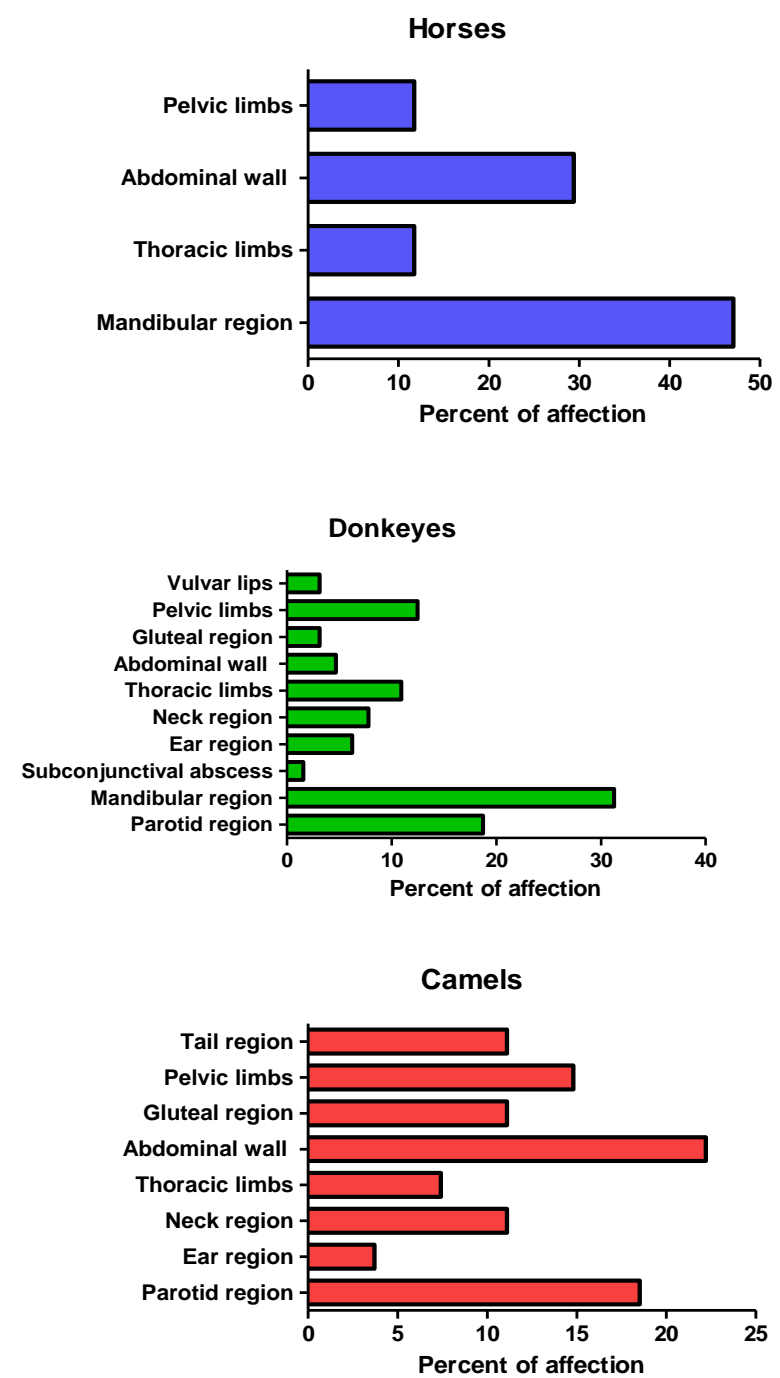

Fig. 2: The percent of affected horses, donkeys, and camels in relation to the seat of body surface abscesses. 
2- The potential causes of abscesses in relation to different predilection seats (table 2).
The ways of entrance of infection were suspected because it is impossible to known accurately the way for infection of each case alone.

Table 2: the Potential causes of abscesses in relation to predilection seats.

\begin{tabular}{|c|c|c|}
\hline No & Region & Potential causes \\
\hline $\mathbf{1}$ & Parotid region & $\begin{array}{ll}- & \text { Lymph-borne infection. } \\
- & \text { Skin breach. }\end{array}$ \\
\hline 2 & Mandibular region & $\begin{array}{ll} & \text { Migrating infected foreign body from the mouth cavity. } \\
\text { - } & \text { Lymph-borne infection. } \\
\text { - } & \text { Blood - borne infection. }\end{array}$ \\
\hline 3 & Sub-conjunctival (s/c) & - $\quad$ Entrance of infection S/C by infected foreign body. \\
\hline 4 & Cheek region & $\begin{array}{l}\text { - Oral abrasions and punctures associated with dental disease or } \\
\text { hard plant awns, etc. }\end{array}$ \\
\hline 5 & Neck region & $\begin{array}{ll}- & \text { Lymph-borne infection. } \\
\text { - } & \text { Skin breach or trauma. }\end{array}$ \\
\hline 6 & Ear region & - $\quad$ Skin breach. \\
\hline 7 & Thoracic limbs & $\begin{array}{ll}- & \text { Lymph-borne infection. } \\
- & \text { Complications of lumby skin disease. }\end{array}$ \\
\hline 8 & Chest wall behind the elbow & - $\quad$ Migrating foreign bodies from the reticulum. \\
\hline 9 & Abdominal wall & - $\quad$ Skin breach. \\
\hline 10 & Umbilical region & - $\quad$ Infection of the Umbilicus. \\
\hline 11 & Pelvic limbs & - $\quad$ Complications of Lumpy skin disease. \\
\hline 12 & Gluteal region & - $\quad$ Intra-muscular injection via infected needle. \\
\hline 13 & Perineal region & $\begin{array}{ll}- & \text { Skin breach. } \\
- & \text { Penetrating foreign bodies. }\end{array}$ \\
\hline 14 & Tail region & $\begin{array}{ll}- & \text { Skin breach. } \\
- & \text { Penetrating foreign bodies. }\end{array}$ \\
\hline 15 & Vulvar lips & $\begin{array}{ll}- & \text { Skin breach. } \\
- & \text { Penetrating foreign bodies. }\end{array}$ \\
\hline
\end{tabular}

3- The frequency of occurrence of solitary (S) and multiple (M) abscesses in different animal species (table 3)
Solitary abscesses were observed in a total number of 682 animals $(86.33 \%)$ while animals affected by multiple abscesses were 108 (13.67\%).

Table 3: The classification of affected animals with body surface abscesses into solitary abscesses or multiple abscesses

\begin{tabular}{|c|c|c|c|c|c|c|c|c|c|c|c|c|c|c|c|c|c|}
\hline \multirow{2}{*}{ Regions } & \multicolumn{2}{|c|}{ Buffaloes } & \multicolumn{2}{|c|}{ Cattle } & \multicolumn{2}{|c|}{ Sheep } & \multicolumn{2}{|c|}{ Goats } & \multicolumn{2}{|c|}{ Donkeys } & \multicolumn{2}{|c|}{ Horses } & \multicolumn{2}{|c|}{ Camels } & \multicolumn{2}{|c|}{ Subtotal } & \multirow{2}{*}{ Tota } \\
\hline & $\mathrm{S}$ & $\mathrm{M}$ & $\mathrm{S}$ & $\mathrm{M}$ & $\mathrm{S}$ & $\mathrm{M}$ & $\mathrm{S}$ & $\mathrm{M}$ & $\mathrm{S}$ & $\mathrm{M}$ & $\mathrm{S}$ & $\mathrm{M}$ & $\mathrm{S}$ & $\bar{M}$ & $\mathrm{~S}$ & $\mathrm{M}$ & \\
\hline Parotid region & 5 & -- & 6 & 1 & 50 & 26 & 14 & 10 & 9 & 3 & -- & -- & 5 & -- & 89 & 40 & 129 \\
\hline $\begin{array}{c}\text { Mandibular } \\
\text { region }\end{array}$ & 4 & -- & 17 & -- & 55 & -- & 16 & -- & 20 & -- & 8 & -- & -- & -- & 120 & -- & 120 \\
\hline Sub-conjunctival & 16 & -- & 15 & -- & 3 & -- & 1 & -- & 1 & -- & -- & -- & -- & -- & 36 & -- & 36 \\
\hline Cheek region & 15 & -- & 11 & -- & 3 & -- & 4 & -- & -- & -- & -- & -- & -- & -- & 33 & -- & 33 \\
\hline Ear region & -- & -- & -- & -- & 3 & -- & 2 & - & 4 & -- & - & -- & 1 & -- & 10 & -- & 10 \\
\hline Neck region & 7 & -- & 13 & 1 & 13 & 2 & 1 & 2 & 5 & - & - & -- & 3 & -- & 42 & 5 & 47 \\
\hline Thoracic limbs & 6 & 6 & 15 & 14 & 10 & 4 & 4 & 2 & 6 & 1 & 2 & -- & 2 & -- & 45 & 27 & 72 \\
\hline $\begin{array}{c}\text { Thoracic wall } \\
\text { behind the elbow }\end{array}$ & 15 & -- & 14 & -- & 5 & -- & -- & -- & -- & -- & -- & -- & -- & -- & 34 & -- & 34 \\
\hline Abdominal wall & 12 & -- & 5 & -- & 14 & 10 & 4 & 1 & 3 & -- & 5 & -- & 6 & -- & 49 & 11 & 60 \\
\hline Umbilical region & 25 & -- & 34 & -- & 7 & -- & 2 & -- & - & - & - & -- & -- & -- & 68 & -- & 68 \\
\hline Gluteal region & 12 & 1 & 21 & 2 & 2 & -- & 2 & -- & 2 & -- & -- & -- & 3 & -- & 42 & 3 & 45 \\
\hline Pelvic limbs & 5 & 1 & 41 & 20 & 10 & - & 11 & - & 8 & - & 2 & -- & 4 & -- & 81 & 21 & 102 \\
\hline Perineal region & 1 & -- & 5 & -- & 2 & -- & 5 & -- & -- & -- & -- & -- & - & -- & 13 & -- & 13 \\
\hline Tail region & -- & - & 2 & -- & 10 & 1 & - & - & - & - & - & -- & 3 & -- & 15 & 1 & 16 \\
\hline Vulvar lips & -- & -- & 3 & -- & -- & -- & -- & -- & 2 & -- & -- & -- & -- & -- & 5 & -- & 5 \\
\hline Total & 123 & 8 & 202 & 38 & 187 & 43 & 66 & 15 & 60 & 4 & 17 & -- & 27 & -- & 682 & 108 & \\
\hline$\%$ & 15.7 & 1.2 & 25.6 & 4.8 & 23.6 & 5.3 & 8.3 & 1.8 & 7.6 & 0.5 & 2.2 & -- & 3.4 & -- & 86.3 & 13.7 & 790 \\
\hline
\end{tabular}




\section{4- Methods of surgical treatment.}

Two surgical approaches were performed for treatment of body surface abscesses (table 4) either by incision and evacuation of abscess contents (I) or by en bloc excision (E). Affected animals with body surface abscesses are classified according to the treatment option into 686 animals $(68.85 \%)$ treated by incision and evacuation and 104 animals (13.15\%) by en bloc excision.

Table 4: Classification of affected animals according to surgical treatment option either by incision (I) and evacuation or en bloc excision (E).

\begin{tabular}{|c|c|c|c|c|c|c|c|c|c|c|c|c|c|c|c|c|c|}
\hline \multirow[b]{2}{*}{ Regions } & \multicolumn{2}{|c|}{ Buffaloes } & \multicolumn{2}{|c|}{ Cattle } & \multicolumn{2}{|c|}{ Sheep } & \multicolumn{2}{|c|}{ Goats } & \multicolumn{2}{|c|}{ Donkeys } & \multicolumn{2}{|c|}{ Horses } & \multicolumn{2}{|c|}{ Camels } & \multicolumn{2}{|c|}{ Subtotal } & \multirow{2}{*}{ Total } \\
\hline & $\mathbf{I}$ & $\mathbf{E}$ & $\mathbf{I}$ & $\mathbf{E}$ & $\mathbf{I}$ & $\mathbf{E}$ & $\mathbf{I}$ & $\mathbf{E}$ & $\mathbf{I}$ & $\mathbf{E}$ & $\mathbf{I}$ & $\mathbf{E}$ & $\mathbf{I}$ & $\mathbf{E}$ & $\mathbf{I}$ & $\mathbf{E}$ & \\
\hline Parotid region & 5 & -- & 17 & -- & 76 & -- & 24 & -- & 12 & -- & -- & -- & 5 & -- & 129 & -- & 129 \\
\hline $\begin{array}{l}\text { Mandibular } \\
\text { region }\end{array}$ & 2 & 2 & 10 & 7 & 24 & 31 & 10 & 6 & 20 & -- & 8 & -- & -- & -- & 74 & 46 & 120 \\
\hline Sub-conjunctival & 16 & -- & 15 & -- & 3 & -- & 1 & -- & 1 & -- & -- & -- & -- & -- & 36 & -- & 36 \\
\hline Cheek region & 15 & -- & 11 & -- & 3 & -- & 4 & -- & -- & -- & -- & -- & -- & -- & 33 & -- & 33 \\
\hline Ear region & -- & -- & -- & -- & 2 & 1 & 1 & 1 & 4 & -- & -- & -- & 1 & -- & 8 & 2 & 10 \\
\hline Neck region & 6 & 1 & 13 & 1 & 10 & 5 & 2 & 1 & 5 & -- & -- & -- & 3 & -- & 39 & 8 & 47 \\
\hline Thoracic limbs & 12 & -- & 28 & 1 & 10 & 4 & 5 & 1 & 7 & -- & 2 & -- & 2 & -- & 64 & 6 & 72 \\
\hline $\begin{array}{c}\text { Thoracic wall } \\
\text { behind the elbow }\end{array}$ & 15 & -- & 14 & -- & 5 & -- & -- & -- & -- & -- & -- & -- & -- & -- & 34 & -- & 34 \\
\hline Abdominal wall & 12 & -- & 5 & -- & 20 & 4 & 5 & -- & 3 & -- & 5 & -- & 6 & -- & 56 & 4 & 60 \\
\hline Umbilical region & 15 & 10 & 20 & 14 & 5 & 2 & 1 & 1 & -- & -- & - & -- & -- & -- & 41 & 27 & 68 \\
\hline Gluteal region & 13 & -- & 23 & -- & 2 & -- & 2 & -- & 2 & -- & -- & -- & 3 & -- & 45 & -- & 45 \\
\hline Pelvic limbs & 6 & -- & 61 & -- & 10 & -- & 10 & 1 & 8 & -- & 2 & -- & 6 & -- & 101 & 1 & 102 \\
\hline Perineal region & 1 & -- & 4 & 1 & 2 & -- & 4 & 1 & -- & -- & -- & -- & -- & -- & 11 & 2 & 13 \\
\hline Tail region & -- & -- & -- & 2 & 6 & 5 & -- & -- & -- & -- & -- & -- & 3 & -- & 9 & 7 & 16 \\
\hline Vulvar lips & -- & -- & 2 & 1 & -- & -- & -- & -- & 2 & -- & -- & -- & -- & -- & 4 & 1 & 5 \\
\hline Total & 118 & 13 & 213 & 27 & 178 & 52 & 69 & 12 & 64 & -- & 17 & -- & 27 & -- & 686 & 104 & \\
\hline$\%$ & 14.9 & 1.7 & 27.0 & 3.4 & 22.5 & 6.6 & 8.7 & 1.5 & 8.1 & -- & 2.2 & -- & 3.4 & -- & 86.8 & 13.2 & \\
\hline
\end{tabular}

5- The fate of cases after surgical treatment. They are classified according to the following:

1) Animals completely recovered after first surgical interference within 7-30 days with formation of scar tissue at the seat of abscess (589 animals $=$ $74.56 \%)$.

2) Animals recovered after the second surgical interference and after treatment of complications within 30-60 days (66 animals $=8.35 \%)$.

3) Culling of animals either by slaughtering or euthanasia (43 animals $=5.44 \%)$.
4) Fate of animals was not recorded postoperatively (92 animals $=11.65 \%)$.

Recorded complications after surgical treatment (66 animals) include; recurrence of abscess at the same or another place (54 animals), sinus formation (9 animals), and ulcer formation (3 animals).

Complete recovery after the first surgical interference occurred in $74.56 \%$ of cases and after the second trail in $8.35 \%$. A percent of $5.44 \%$ of animals were culled either by slaughtering or euthanasia and $11.65 \%$ was not recorded (Table 5). 
Table 5: The fate of treatment of body surface abscesses.

\begin{tabular}{lccccc}
\hline Regions Animals & $\begin{array}{c}\text { Complete } \\
\text { recovery }\end{array}$ & $\begin{array}{c}\text { Recovery } \\
\text { from } \\
\text { second trial }\end{array}$ & Culling & $\begin{array}{c}\text { Not } \\
\text { recorded }\end{array}$ & Total \\
\hline Parotid region & 89 & 21 & 10 & 9 & 129 \\
\hline Mandibular region & 100 & 5 & 3 & 12 & 120 \\
\hline Sub-conjunctival & 35 & 1 & -- & -- & 36 \\
\hline Cheek region & 28 & 2 & -- & 3 & 33 \\
\hline Ear region & 8 & -- & -- & 2 & 10 \\
\hline Neck region & 42 & 2 & -- & 3 & 47 \\
\hline Thoracic limbs & 32 & 5 & 15 & 20 & 72 \\
\hline Thoracic wall behind the elbow & 27 & 1 & 3 & 3 & 34 \\
\hline Abdominal wall & 48 & 2 & -- & 10 & 60 \\
\hline Umbilical region & 58 & 4 & 1 & 5 & 68 \\
\hline Gluteal region & 35 & 6 & 1 & 3 & 45 \\
\hline Pelvic limbs & 57 & 14 & 10 & 21 & 102 \\
\hline Perineal region & $\mathbf{7 4 . 5 6}$ & $\mathbf{8 . 3 5}$ & $\mathbf{5 . 4 4}$ & $\mathbf{1 1 . 6 5}$ & $\mathbf{1 0 0 \%}$ \\
\hline Tail region & 5 & 1 & -- & 1 & 13 \\
\hline Vulvar lips & $\mathbf{5 8}$ & -- & -- & 16 \\
\hline
\end{tabular}

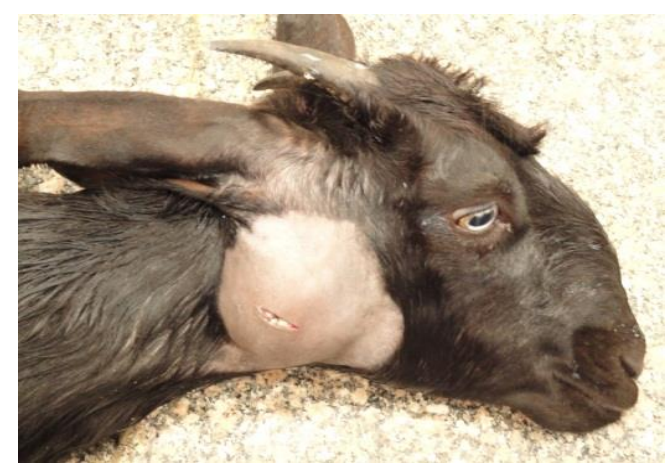

Fig. 3: Abscess at the parotid region in a sheep.

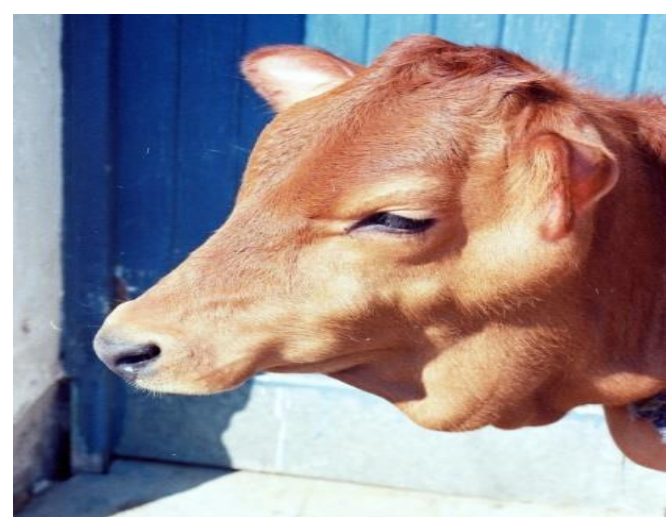

Fig. 5: Multiple abscesses below the ear, parotid region, cheek and mandibular region in a calf.

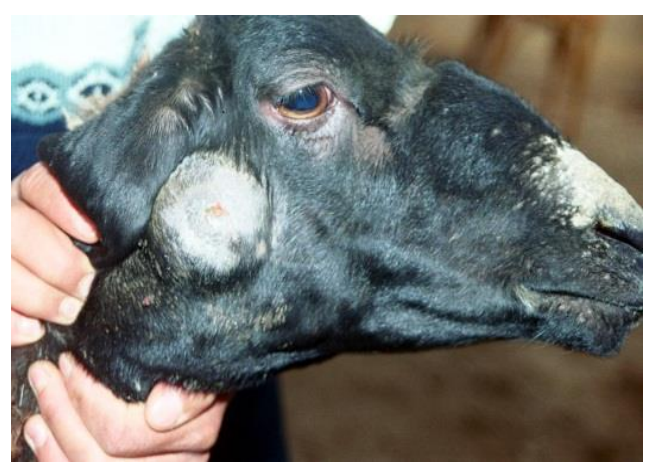

Fig. 4: Abscess at the parotid region in a sheep.

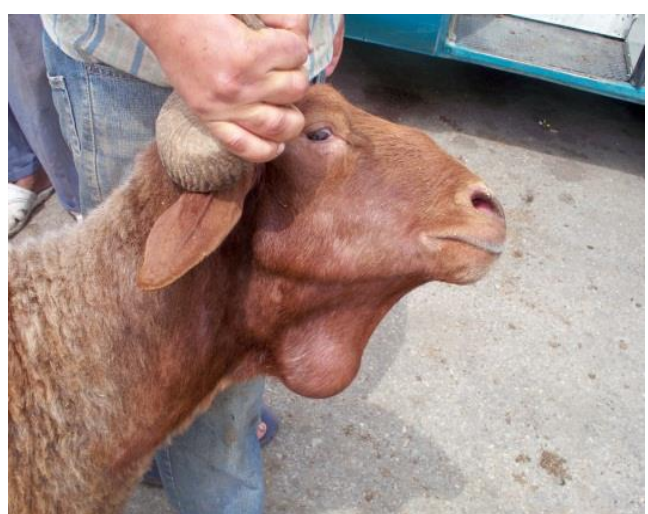

Fig. 6: Abscess at the mandibular region in a sheep. 


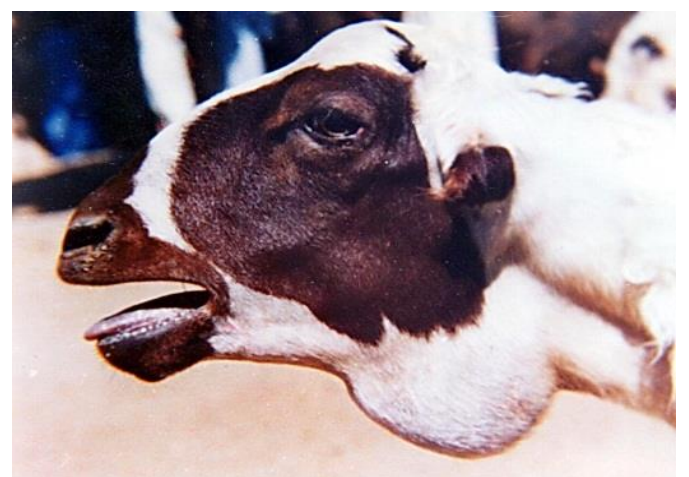

Fig. 7: Abscess at the mandibular region in a goat.

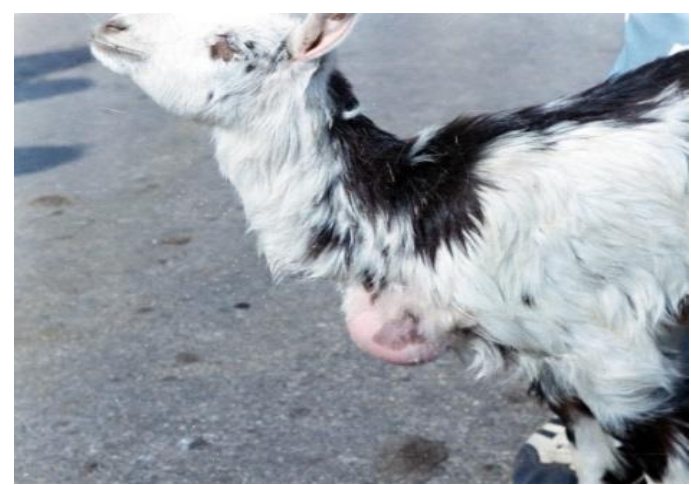

Fig. 9. Abscess at the base of the neck in a goat

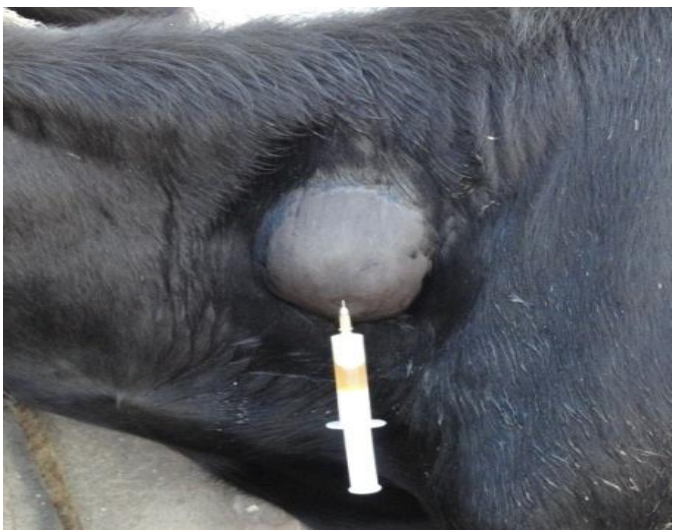

Fig. 11: Aspiration of pus from an abscess.

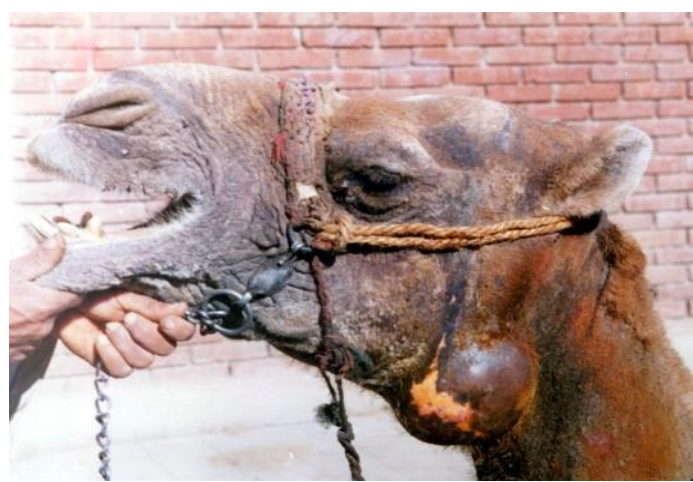

Fig. 13: Abscess behind the mandibular angle in a camel.

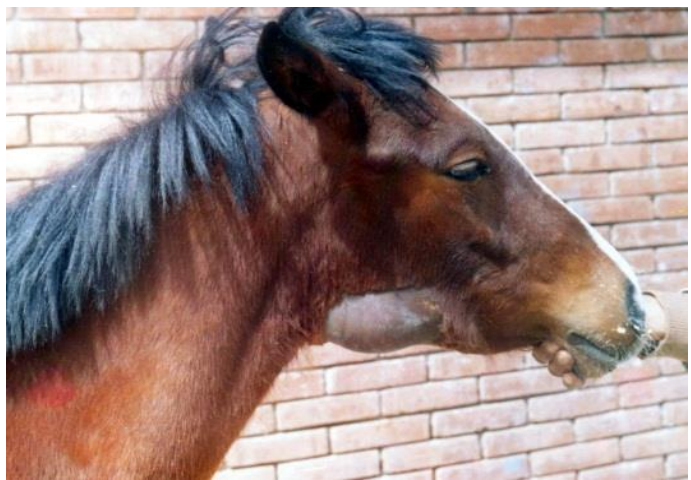

Fig. 8: Abscess at the mandibular region due to strangles in a foal.

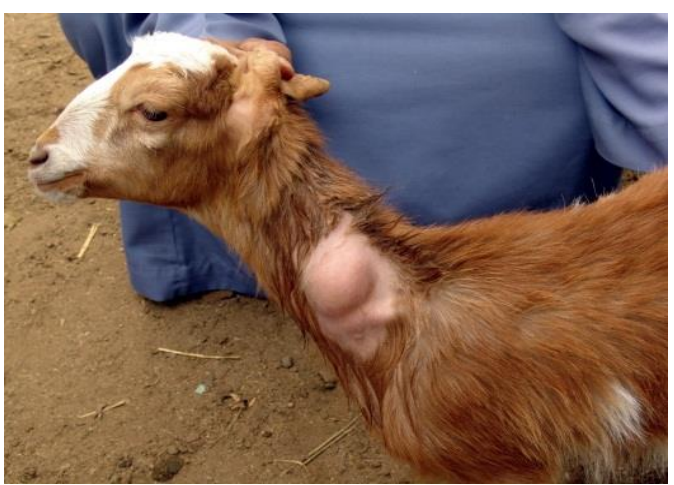

Fig. 10: Abscess at the lateral aspect of the neck in a goat.

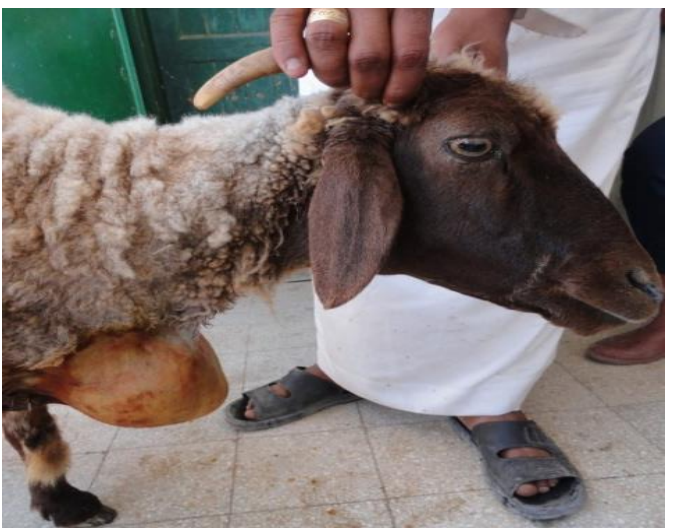

Fig. 12: Presternal abscess in a sheep.

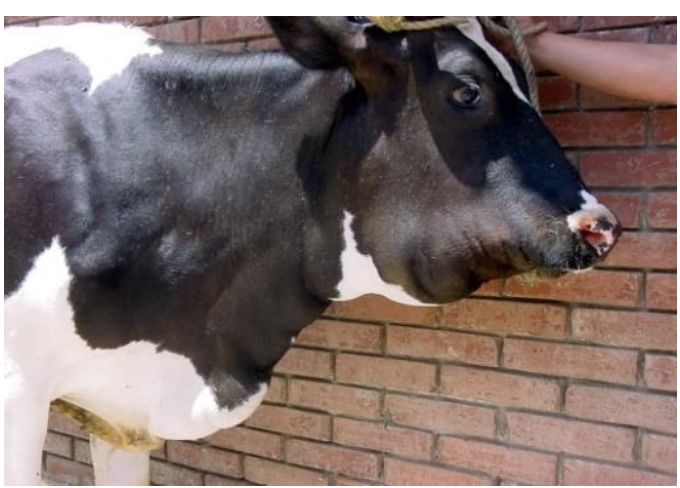

Fig. 14: Foreign body abscess at the mandibular region in a cow. 


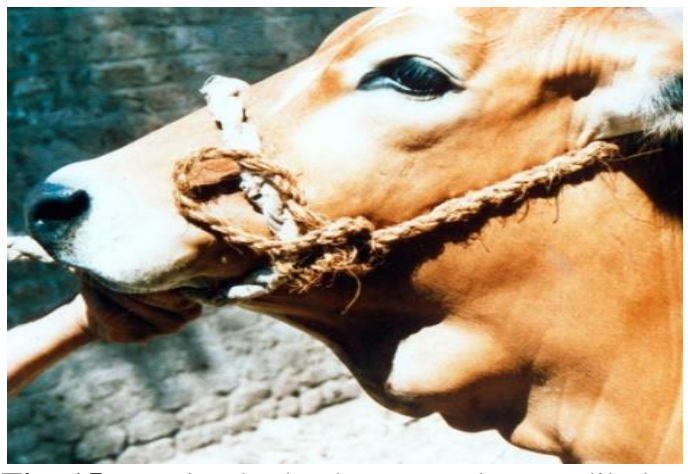

Fig. 15: Foreign body abscess at the mandibular region in a cow.

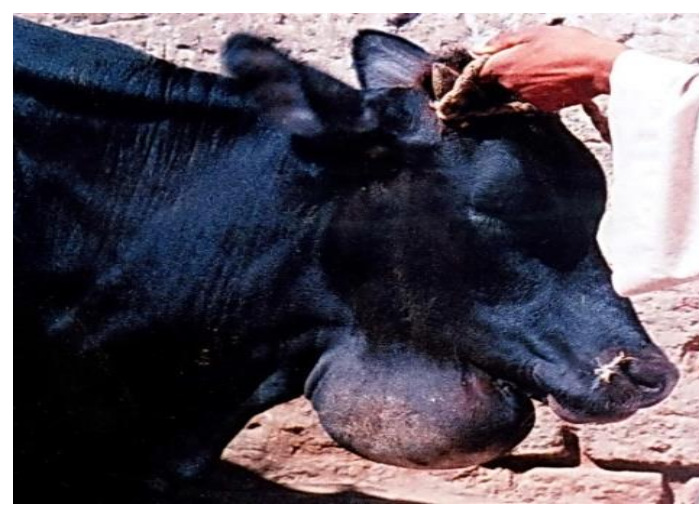

Fig. 17: A huge foreign body abscess at the mandibular region in a cow.

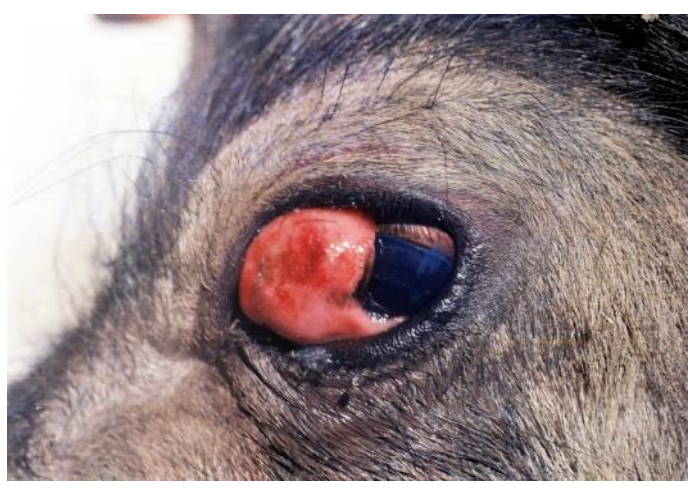

Fig. 19: Third eyelid abscess in a buffalo.

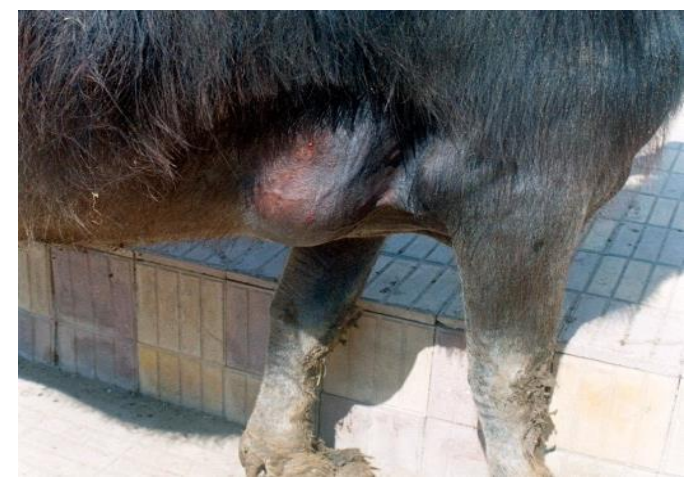

Fig. 21: Foreign body abscess at the chest wall behind the elbow in a buffalo.

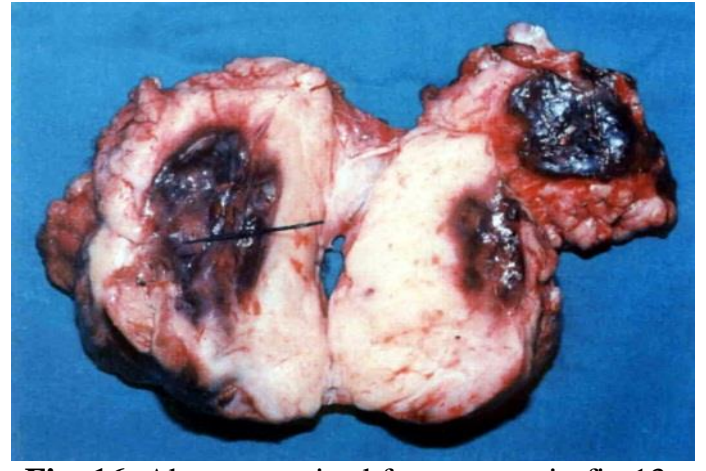

Fig. 16: Abscess excised from a cow in fig 13. Note a needle inside it.

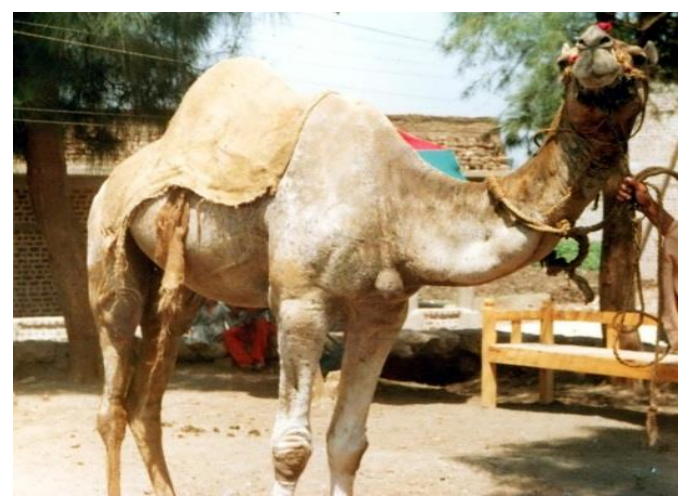

Fig. 18: Abscess at the base of the neck in a camel.

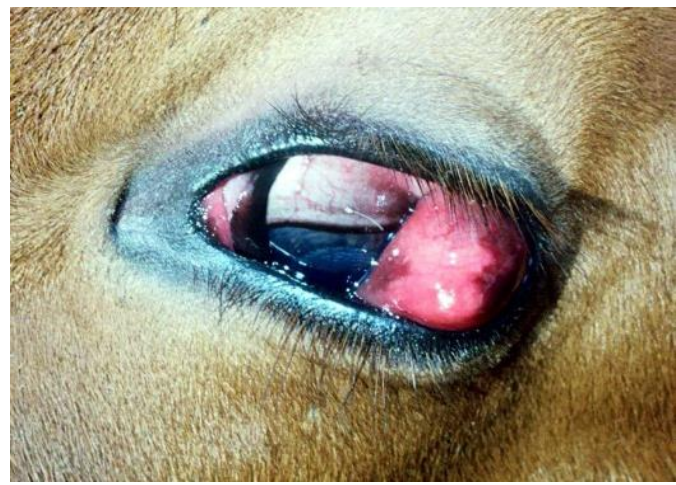

Fig. 20. Subconjunctival abscess in a cow.

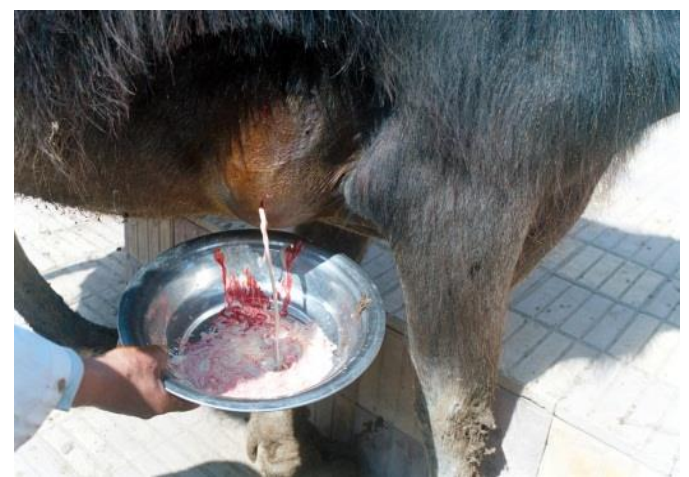

Fig. 22: Evacuation of an abscess in fig. 21. 


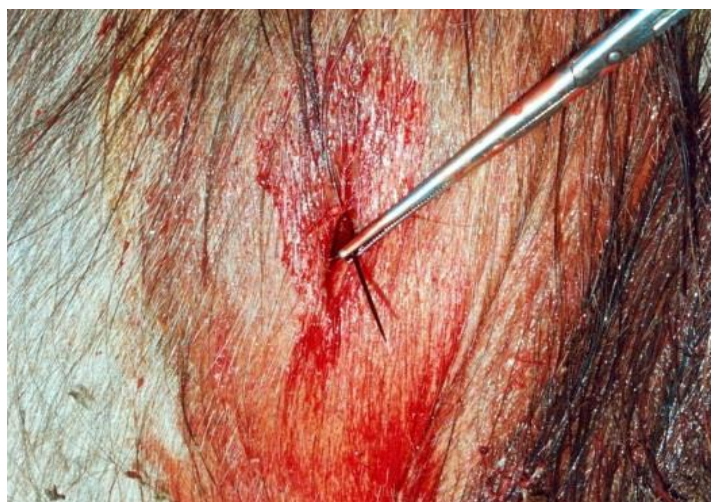

Fig. 23: Extraction of a needle from the abscess in fig. 21.

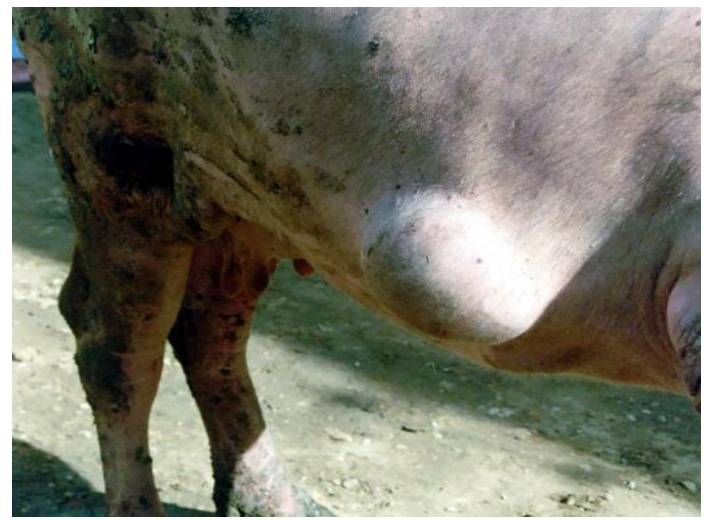

Fig. 25: Abscess at the lateral thoracic wall in a buffalo.

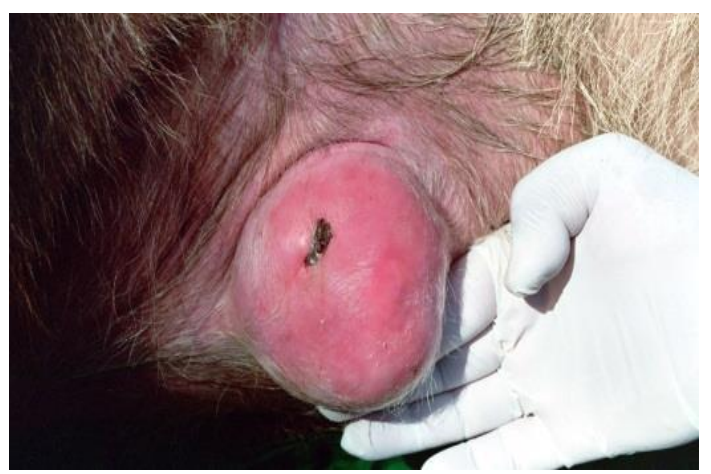

Fig. 27: Umbilical abscess in a buffalo calf.

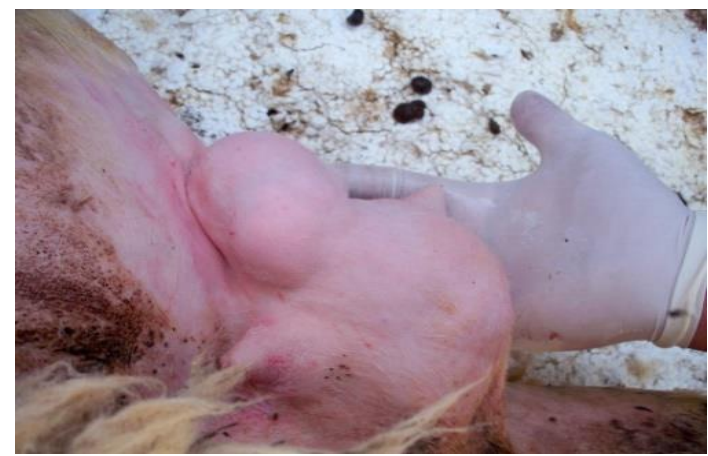

Fig. 29: Abdominal abscess in front of the udder in a sheep.

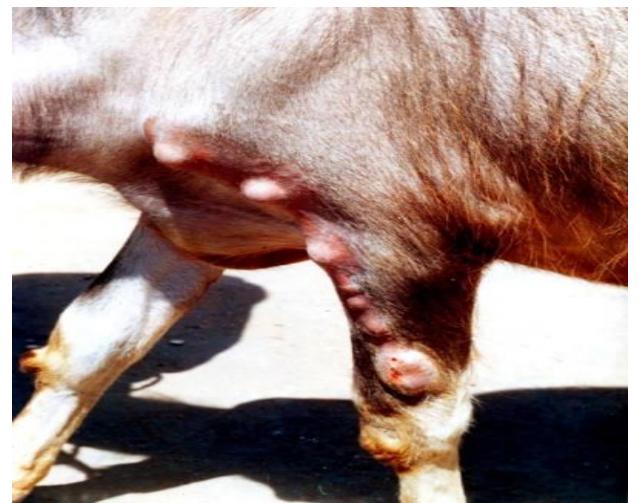

Fig. 24: Multiple abscesses along the lymphatic vessels of the thoracic limb in a buffalo.

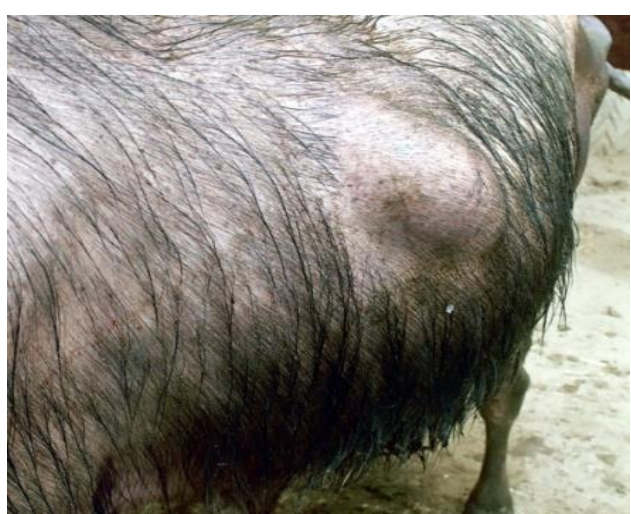

Fig. 26: Abscess at the lateral abdominal wall in a buffalo.

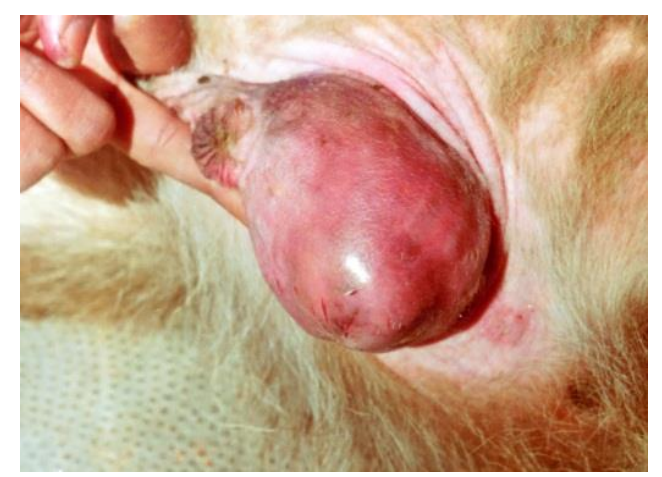

Fig. 28: Umbilical abscess in a calf.

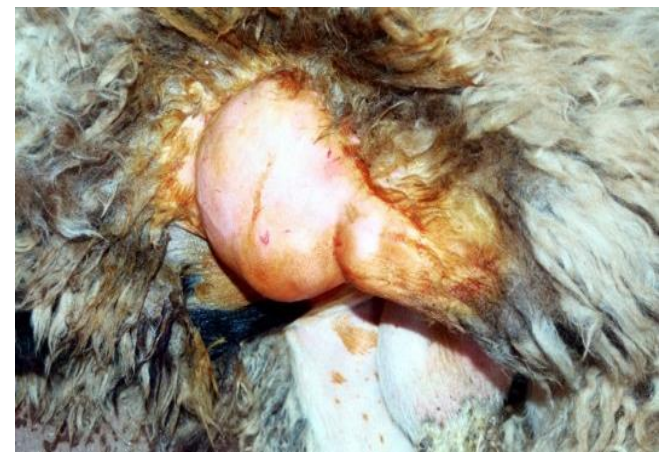

Fig. 30: Abscess at the base of the scrotum as a complication of castration by Burdizzo in a sheep. 


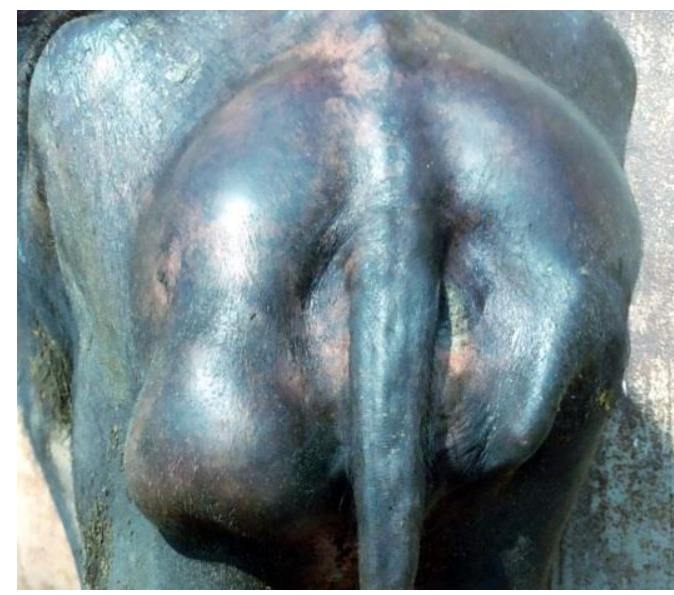

Fig. 31: A huge abscess at the pelvic region due to intramuscular injection in a buffalo.

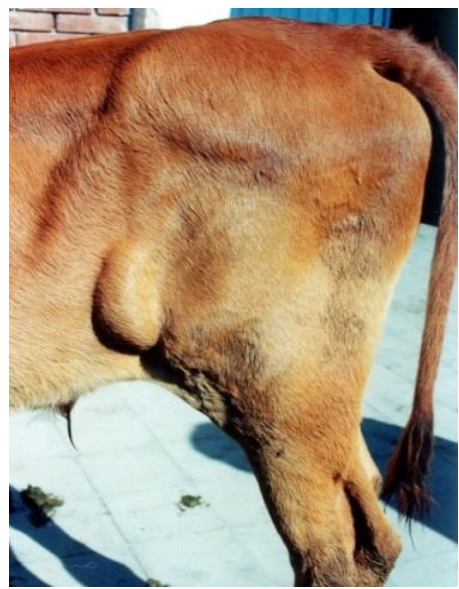

Fig. 32: Prefemoral abscess due to caseous lymphadenitis in a cow.

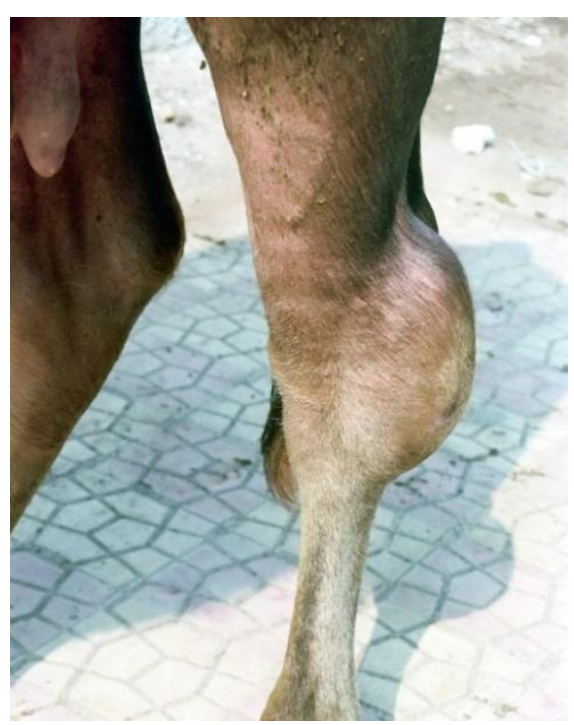

Fig. 33: Abscess at the lateral aspect of the hock in a cow.

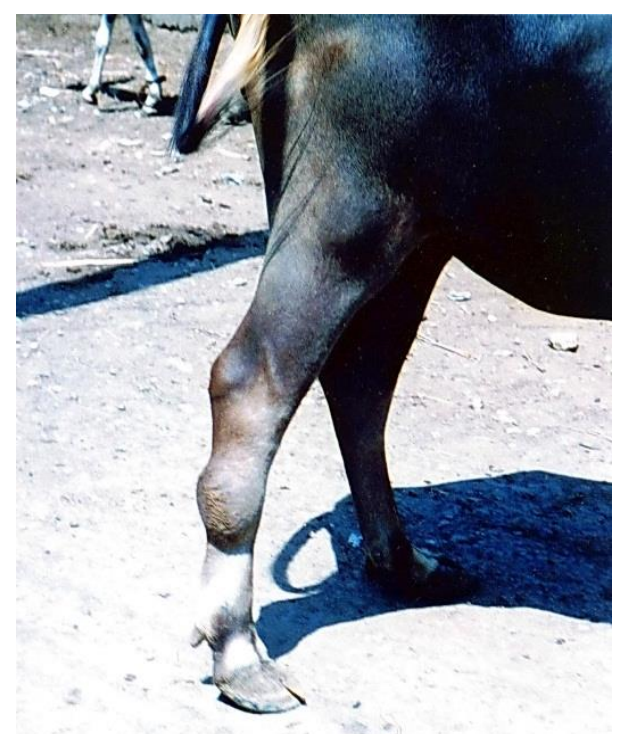

Fig. 35: Abscess at the lateral aspect of metatarsus in a buffalo.

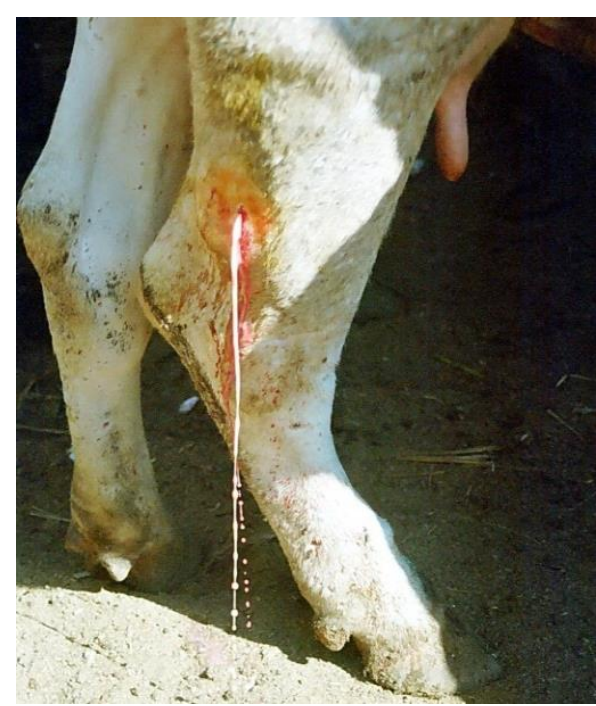

Fig. 34: Evacuation of abscess at the lateral aspect of the gaskin in a cow.

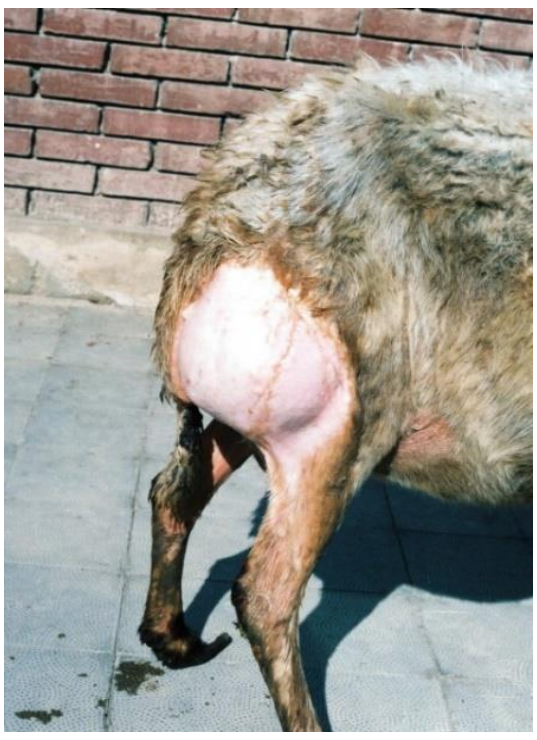

Fig. 36: Abscess at the lateral aspect of the thigh in a sheep. 


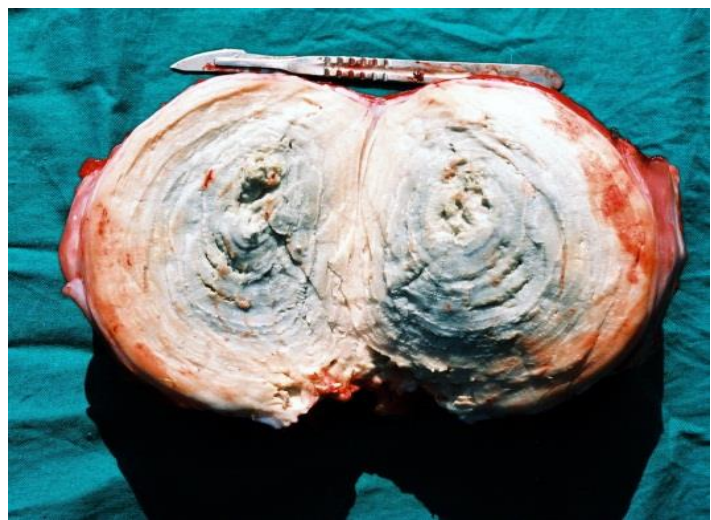

Fig. 37: Cross section of the excised abscess showing onion-like pattern of the inspissated pus of case in fig. 36 .

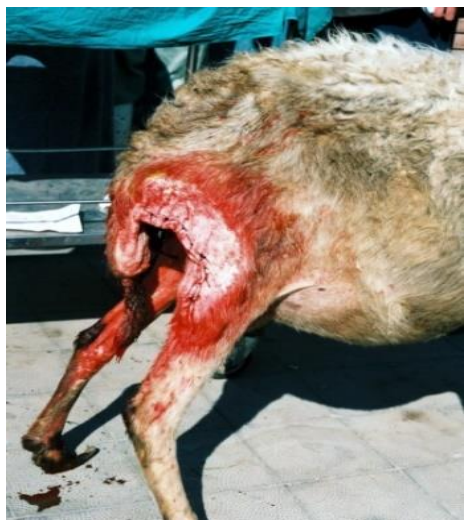

Fig. 38: Case shown in fig. 36 after excision of the abscess

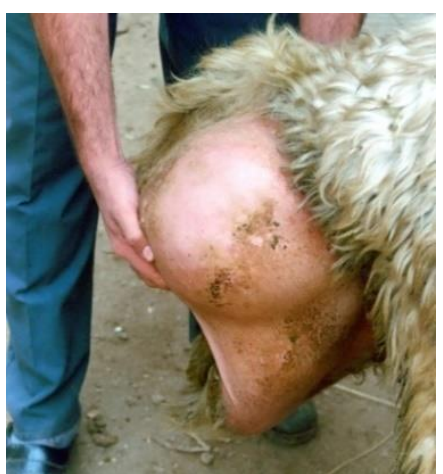

Fig. 39: A huge abscess at the tail of a sheep.

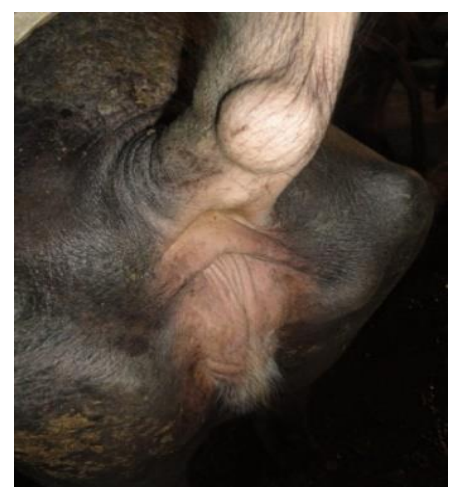

Fig. 41: Abscess at the ventral aspect of the tail in a buffalo.

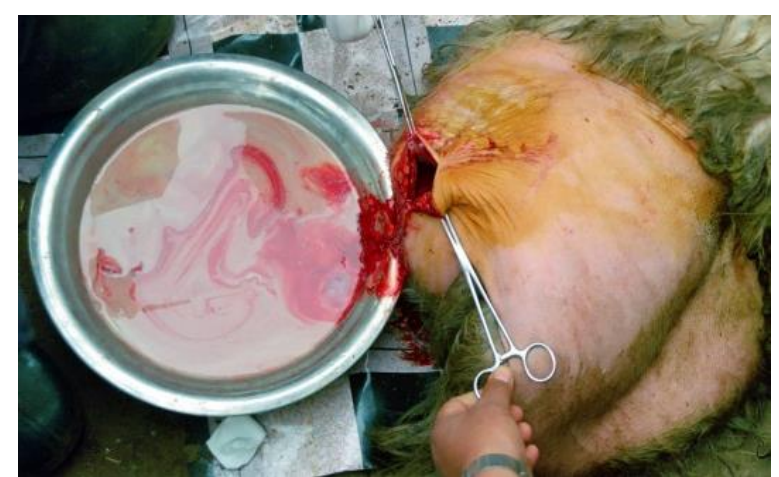

Fig. 40: The same case shown in fig. 39 during abscess evacuation.

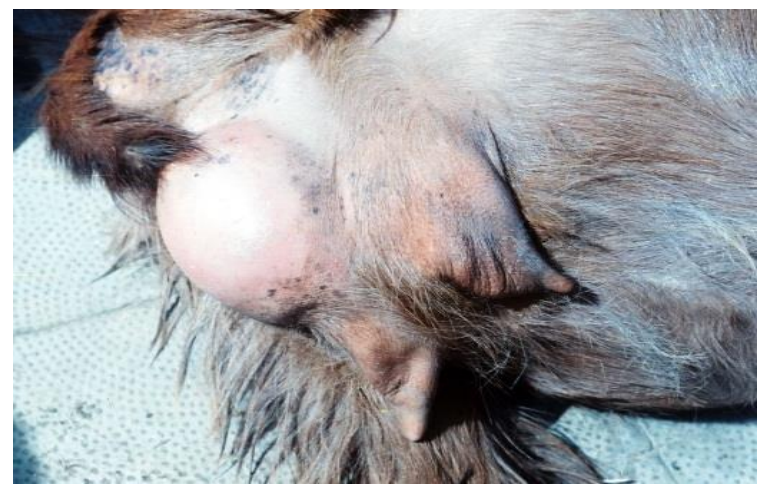

Fig. 42: Supramammary gland abscess in a goat.

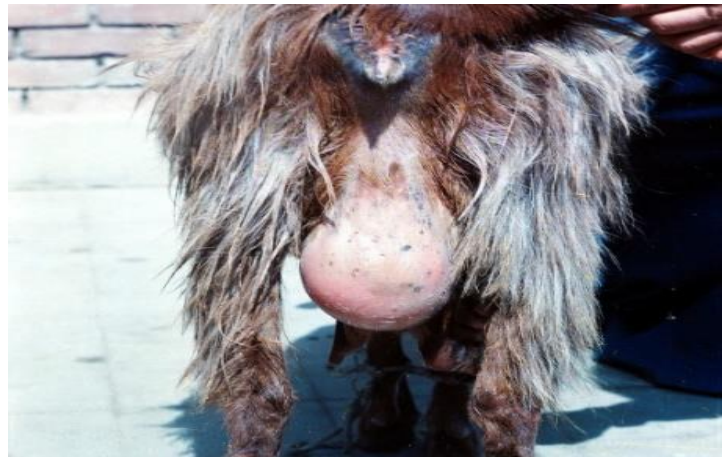

Fig. 43: Supramammary gland abscess in a goat.

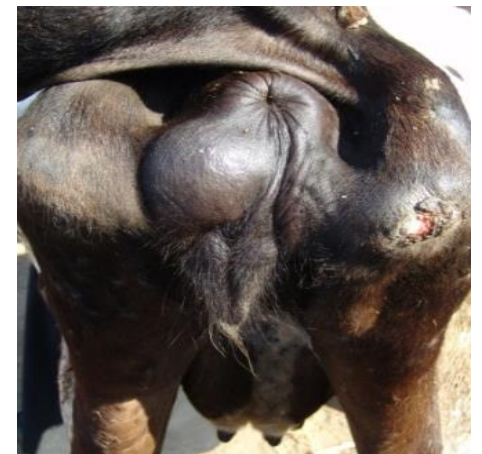

Fig. 44: Vulvar abscess in a cow. 


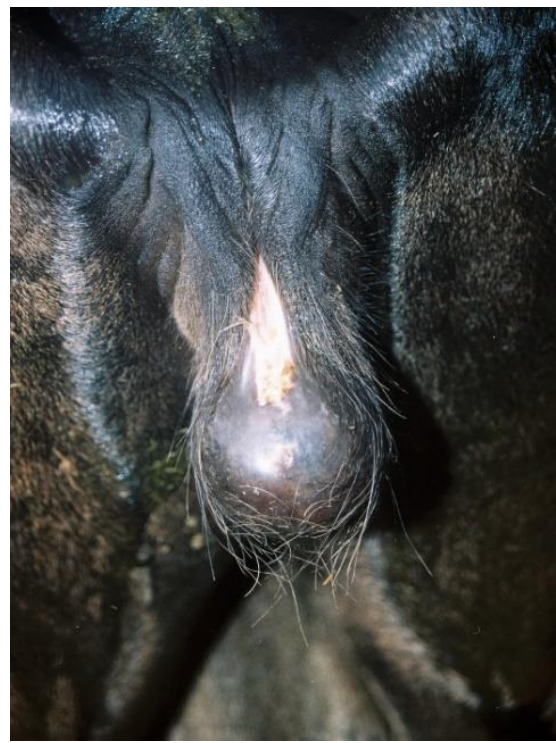

Fig. 45: Abscess at the lower commissure of the vulva in a buffalo.

\section{DISCUSSION}

Causes of abscess formation in farm animals are variable and include a breach on the surface of the skin or mucous membrane and entrance of pyogenic microorganisms through it, infected foreign bodies migrating from the lumen of digestive tract, nonsterilized needle used for intramuscular injection, punctured wounds induced by infected foreign bodies and blood and lymph-borne infection (Fubini et al., 2004; Misk et al., 2008; Misk et al., 2016 and Misk et al., 2019).

Predilection seats of abscesses in different farm animals depend mainly on the way of entrance of infection. Abscesses at the parotid and mandibular regions are due to either infected foreign body penetrating the oral mucosa and soft tissues or due to lymphatic borne infection. In the present study the most common animals affected with abscesses at the submandibular region were sheep due to caseous lymphadenitis. Transmission of caseous lymphadenitis occurs via ingestion or inhalation of infected bacteria from the environment. The organisms gain access to the body via break in the skin during shearing or dipping for external parasite. Lymph nodes at the mandibular and parotid regions as well as at the neck and hind legs often have abscesses in sheep. The abscesses are multiple and appear as firm masses that can be expressed intact by surgical excision and often has a laminar appearance when cut in cross section (Williamson et al., 2001; Misk et al., 2008 and Fontasine et al., 2008).

Strangles is one of the first equine diseases described in the literatures. It is characterized by sudden onset of fever and upper respiratory catarrh, followed by acute swelling and subsequent abscess formation in the sub-maxillary, sub-mandibular and retropharyngeal lymph nodes (Reile et al., 1983; Sweeny et al., I 1987 and Sweeny et al., II 1987). In the present study abscesses at the mandibular region in donkeys and horses were due to strangle infection.

Sub-conjunctival and third eyelid abscesses are usually due to penetration of the conjunctiva with infected foreign body present accidently in the conjunctival cul-de-sac. Continuous blepharospasm may force the foreign body to penetrate the palpebral or bulbar conjunctiva and inoculate infection subconjunctively with subsequent formation of abscesses (Misk et al., 1986; Lavach et al., 1990 and Misk et al., 2014). This condition was recorded frequently in buffaloes and cattle in the present study.

Cheek abscesses were also diagnosed in ruminants. Oral abrasions, openings and punctures associated with dental disease, hard plant awns, thorns, stickers or dry coarse stemmed feeds are the way for entrance of either nonspecific microorganisms inducing abscess at the cheek, mandibular space, pharynx and oral cavity or specific microorganisms as actinomyces bovis leading to actinomycosis with formation of granulomatous abscesses in the mandible, maxilla and some soft tissues.

Abscesses at the neck region especially at the base or close to the pre-scapular region are in most instances due to lymph-borne infection as the pre-scapular lymph node may be the seat of caseous lymphadenitis in most animals. Seats of abscesses in sheep and goat were the pre-scapular lymph nodes then the prefemoral lymph nodes (Abebe et al., 2015). Thoracic limbs abscesses were seen in the present study in all animals and appear to be due to lymph borne infection which may lead to caseous lymphadenitis and caseous lymphangitis. 
In most instances, abscess formation adjacent to the reticulum is secondary to hardware disease. In the present study several abscesses were diagnosed in buffaloes, cattle and sheep behind the elbow at the right thoracic wall. Opening and drainage revealed presence of foreign bodies such as sewing needles and pieces of wire (Misk et al., 1981; Misk et al., 2001; Fubini et al., 2004 and Sangwan et al., 2017).

Umbilical abscess or infection of any of the three components of the umbilicus (arteries, veins and urachus) may produce local infection with abscess formation. The source of infection is most commonly the external environment, coupled with failure of passive transfer. Umbilical abscesses were diagnosed in the present study mainly in buffaloes and cattle. They appear as warm, painful, non-reducible and firm or fluctuant mass. Aspiration revealed purulent material from the mass. Most of abscesses will respond to treatment by drainage and lavage of the abscess cavity (Fubini et al., 2004 and Mosbah et al., 2006).

Pelvic limbs abscesses were seen frequently in the present study in cattle and sporadically in goat, sheep and buffaloes. The large number of cases recorded in cattle was due to complications of Lumpy skin disease. The latter is an infectious viral disease characterized by formation of nodules or lumps in the skin covering all parts of the body. Secondary infections sometimes occur and cause extensive suppuration and sloughing of tissues. The hind limbs show signs of inflammation and swellings at the gaskin region. The swelling was filled with pus and threads of necrotic tissues. Opening and drainage were indicated immediately for treatment of such cases (Davies, 1991; Fubini et al., 2004; Pressz et al., 2015 and Tuppurainen, 2018).

Abscesses at the ventral abdominal wall, perineal region, tail and vulvar lips may be due to skin breach or penetration of infected foreign bodies through the soft thin skin at these areas. Gluteal region abscesses were recorded frequently in cattle and buffaloes. This condition appears to be due to intramuscular injection of medicaments with non-sterilized needle (Tuffyli et al., 2012; Pressz et al., 2015 and Attia et al., 2019).

Abscesses around scrotum were sporadically recorded in sheep in the present study due to faulty castration by Burdizo instrument. The most common complications after pig castration were hemorrhage, abscess, scirrhous cord, inguinal hernia and hematoma formation. Abscesses were detected in the present study after castration in the pelvic region (Szazado 1985 and Steerforth et al., 2015).

Solitary abscesses in the present study were diagnosed in 682 animals $(86.33 \%)$ while multiple abscesses were detected in 108 animals (13.67\%). Multiple abscesses were seen when the cause was blood or lymph - borne infection as in cases of caseous lymphangitis and caseous lymphadenitis in cattle, sheep and goats.

Multiple abscesses were detected at the parotid and mandibular regions, thoracic limbs and pre-femoral lymph node, while solitary abscesses (one abscess per one animal) were detected when the cause is breach on the skin surface, penetrating foreign bodies, intramuscular injection with infected needle and migrating foreign bodies from the digestive tract (Misk et al., 1985; Misk et al., 2008 and Misk et al., 2014).

Concerning surgical treatment of abscesses, the authors of the present study suggested two approaches for correction of such cases. The first approach is the opening of the abscess after maturation and evacuation of its contents. The second is the en bloc excision of abscess. The first option is performed when the abscess has no limitations and extended under the surface of the skin as well as close to a vital structure while the second option is performed when the abscess is well circumscribed, firm and movable under the skin. Moreover, the first approach takes a long time for healing (20-30 days) and needs daily wound management for healing by second intention while the second approach needs not more than 10 days and the skin wound healed by first intention.

Around $75 \%$ of animal were recovered without any postoperative complications. $8 \%$ of animals were added to the recovery group taking in consideration some complications which may supervene during the first trial of treatment. When multiple abscesses were detected in one animal the decision of slaughtering (ruminants) or euthanasia (equine) was taken in $5.44 \%$ of affected animals. Follow up of some treated cases (11.65\%) was not performed due to bad connections or carelessness of owners.

In conclusion, body surface abscess in farm animals are located at specific seats on the animal body. The location of abscesses is related to the way of infection and presented either solitary or multiple. Surgical treatment was successful in most of presented cases.

\section{REFERENCES}

Abebe, A. and Ressema, TS. (2015): Determination of corynebacterium pseudotuberculosis prevalence and antimicrobial susceptibility pattern of isolates from lemph nodes of sheep and goats at an organic export abattoir, Modjo, Ethiopia. Letters in Applied Microbiology ISSN 0266-8254.

Abouelnasr, K.; El-Shafaey, E.; Mosbah, E. and ElKhodery, S. (2016): Utility of ultrasonography for diagnosis of superficial swellings in buffalo (Bubalus bubalis). Journal of 
veterinary medical science 78 (8): 1303-1309. Doi:10.1292/jvms.15-0629.

Attia, NE.; Eisa, EF. and Ezzeldein, SA. (2019): Suppurative injection site lesion in cattle: clinic - biochemical, ultrasonographic and histo pathological examination. Zagazig veterinary journal, Article, Vol, 47, Issue 3, pp $317-329$.

Davies, F.G. (1991): Lumpy skin disease, an African capripox virus disease of cattle. British veterinary Journal. British Veterinary Journal. Volume 147, Issue 6, November-December 1991, Pages 489-503.

Fontasine, MC. and Baird, GJ. (2008): Caseous lymphadenits. Small ruminant research. El Sevier 76, 42-48.

Fubini, SL. and Ducharme (2004): Farm animal surgery. 1st ed. USA: Elsevier, pp: 189 - 195.

Kirkan, S.; Ural, Kb.; Parin, U.; Ortlek, OB.; Balikci, C.; Guletekin, M.; Karademir, U. and Akin, I. (2017): Submandibular and parotid abscess due to Nocardis sp. And therapy with danofloxacin in sheep/ Jhellenic Vet. Med. Soc. 2017, 68(1): 021-026.

Lavach, JD. (1990): Large animal ophthalmology, the C.V. Mosby Company.

Misk, NA. (2019): Fundamentals of general veterinary surgery. Assiut city press, Assiut, Egypt.

Misk, NA. and Amer, AA. (1981): Abnormal path way of sharp foreign body in a buffalo. Veterinare Medisinische Nachrichten, Heft 5, 175 - 176.

Misk, NA. and Ismail, SF. (1986): Surgical management of some ocular diseases in buffaloes, cattle and sheep. Veterinary medical review No.1 pp 55-73.

Misk, NA.; Misk, TN. and Semieka, MA. (2016): Field diagnosis and differential diagnosis of body surface swellings in different domestic animals. $13^{\text {th }}$ congress of Egyptian Society of Cattle Diseases, 1-4 Feb, Hurghada, Egypt.

Misk, NA.; Nigam, JM. and Rifat, TF. (1985): Unual foreign body abscesses at the intermandibular space and pharyngeal region in cows. Assiut vet. Med.J. Vol. 14 No. 27.

Misk, NA.; Semieka, MA. and Ali, El-M. (2001): Varieties and sequellae of ingested foreign bodies in buffaloes and cattle. Assiut Vet, Med, J. Vol 46, No 91.

Misk, NA.; Semieka, MA. and Misk, TN. (2008): Predilection seats of body surface abscesses in relation to the way of infection in some domestic animals. 25th world Buiatrics congress July 6-11, Budapest, Hungary.
Misk, TN. and Misk, NA. (2014): Role of naked - eye examination in diagnosis of ocular affections in cattle and buffaloes with special references to the possibility of treatment. The 28th world Buiatrics Corgress, Cairns, Australia, July 77 1 Aug.

Mosbah, E. and Karrouf, GIA. (2006): Surgical management of certain umbilical affections in calves and foals monifiya veterinary journal. Researchgate.net

Pressz, J Du.; Matan, F. and Henton, M. (2015): Abscesses in livestock: animal health - part 29. Farmer's weekly

Reile, LJ. and Genetyky, RM. (1983): Equine Straingle; a brief overview. Iowa state university veterinarian.

Sadan, M. (2019): Superficial swellings in sheep (ovis aries) and goats (capra hircus): Clinical and ulterasonographic findings. The Journal of Veterinary Medical Science. 81(9):13261333.doi:10.1292/jvms.19-0209.

Sangwan, V.; Yaseen SH.M. Aggarwals and Singhs (2017): Surgical retrieval of sewing needle from the thoracic wall abscess in murrah buffaloes. Intas Polivet, Vol, 18, No.1 pp 52.

Steerforth, O. and Marutsiv, P. (2015): Ulcerative lymphangitis due to corynebacterium pseudotuberculosis in Bulgarian Holstein dairy cows. Veterinary Record. Vet Rec Case Rep 2017;5:e00454. doi:10.1136/vetreccr-2017000454 .

Sweeny, CR.; Benson, CE. and Whitlock, RH. (1987): Strangles infection in horses II, cont Educ 845 -852 .

Sweeny, Cr.; Benson, CE. and Whitlock, RH et al (1987): Strangles infection in horses II, cont Educ 9 (6): 689-695.

Szazado, SI. (1985): Judgement of castration induse abscesses in pigs at meat inspection. Acta Veterinaria Hungarica 33: 177 - 184

Tuffyli, YI KH. and Shekhan, Mi. (2012): Clinical and bacteriological study of subcutaneous abscesses caused by gram positive bacteria in cow and sheep in Al-Qadissiyia province: A;Al-Qadisiyah Journal of Veterinary Medicine Sciences. $\quad$ ISSN: 18185746 23134429, Volume: 11, Issue: 2 Pages: 80-85.

Tuppurainen, ESM. (2018): Introduction to lumpy skin disease. Book of springer link pp1 -2 .

Williamson, LH. (2001): Caseous lymphadenitis in small ruminants. Veterinary clinics of north America Food Animal practice. Volume 17, Issue 2, Pages 359-371. 


\section{دراسة مرجعية علي خراريج سطح الجسم في بعض حيوانات المزرعة \\ طاق نبيل مسك ، تيكور الشري، نبيل أحمد مسك}

E-mail: tarik.misk@vet.usc.edu.eg Assiut University web-site: www.aun.edu.eg

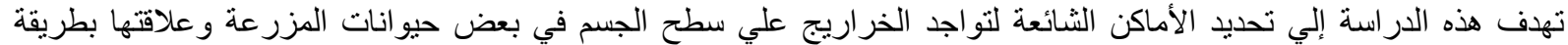

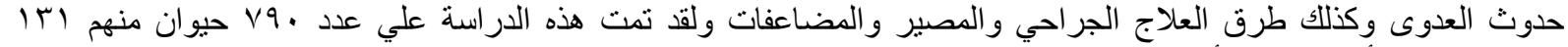

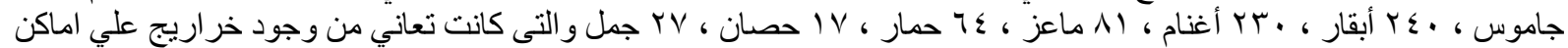

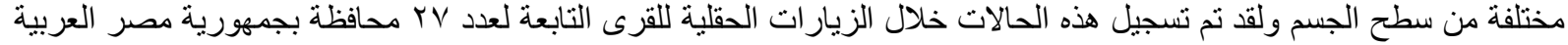

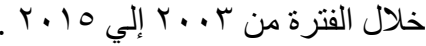

ولقد نم تثخيص هذه الحالات بالاعتماد علي تاريخ الحالة والأعر اض الإكلينيكية والوخز الاستكثافي، وقد تم العلاج الجراحي بفتح

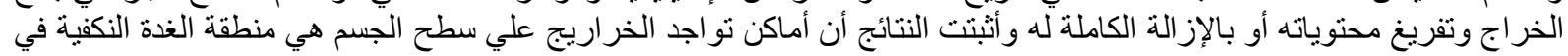

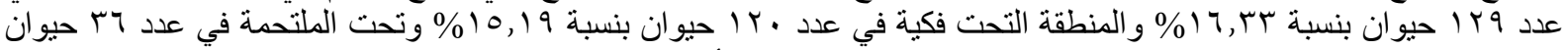

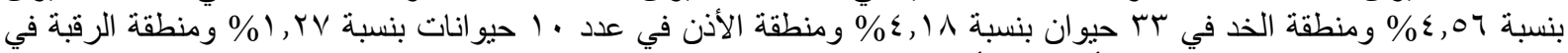

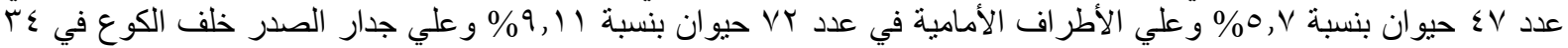

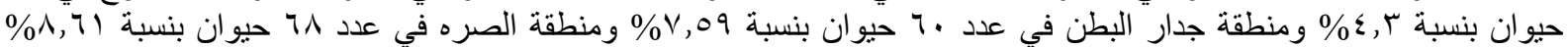

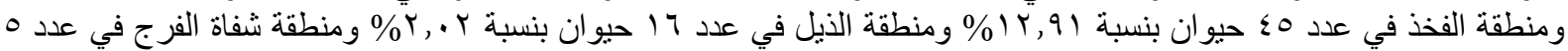

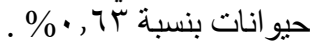

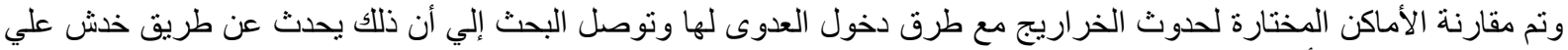

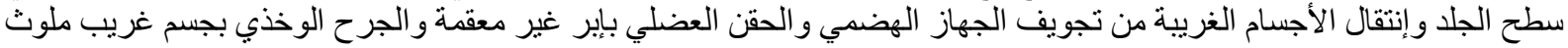
ونقل العدوى عن طريق الليمف و الاد.

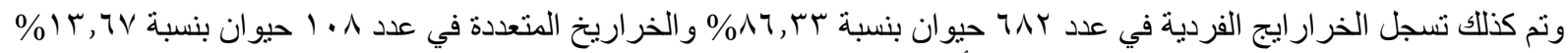

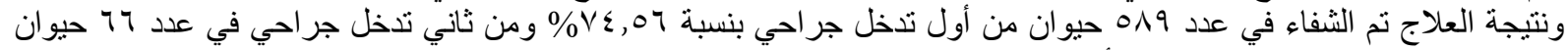

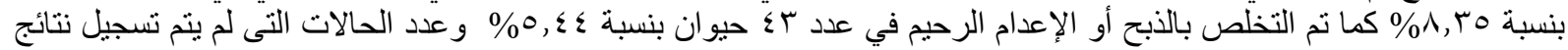

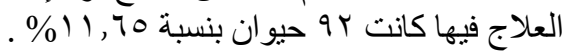

